\title{
Raiganj University \& its Research Activities: A Comprehensive Overview
}

\author{
P.K. Paul ${ }^{*}$, A. Bhuimali ${ }^{2}$ and Kalishankar Tiwary ${ }^{3}$ \\ ${ }^{I}$ Executive Ditector, MCIS, Raiganj University (RGU), West Bengal, India \\ ${ }^{2}$ Vice Chancellor, Raiganj University, West Bengal, India \\ ${ }^{3}$ Dean (Science \& Management), Raiganj University, West Bengal, India \\ *Corresponding author: pkpaul.infotech@gmail.com
}

\begin{abstract}
Raiganj University is a State Government University located at Raiganj, West Bengal. It was established in the year 2015 as a unitary university. Initially the university started with Under-Graduate and Post-Graduate Program and then it has started its Research program leading to MPhil and $\mathrm{PhD}$ programs in different branches of Arts, Science, and Commerce. At present the University holds 22 PG Departments and out of which total 17 Departments have started MPhil \& PhD programs. The university was initiated tagged as a college under the University of North Bengal, WB. The initial development of Raiganj University is noticeable; in the year of establishment itself i.e. 2015 the University started total $10 \mathrm{PhD}$ programs. Then since 2016 the number of subject has been enhanced and thereafter MPhil program also been started. Apart from the research degrees i.e. MPhil and $\mathrm{PhD}$, the university also started higher degrees leading to the D.Sc. and D.Litt. Moreover the university after its establishment within a specific timeframe have done good job in terms of productive research output leading to research papers, policy papers, review papers etc. Importantly the output of the degree within a specific time is noticeable and eye catching. This paper highlightes the emerging areas and research scenario of Raiganj University. It explores the areas, topic, department and faculty wise status in terms of research and development.
\end{abstract}

Keywords: Paper, Research Output, Raiganj University, West Bengal, PhD Output, Quality of Research, Number of research work

The educational developments are very much important for the promotion of societal development [5], [7]. Many universities have been established in recent past in India specially in West Bengal. The paper is conceptual in nature and deals with several aspects of Raiganj University including its year of establishment, number and name of the departments, area of specialization and research experience 
of different departments, the area and subject in which MPhil and $\mathrm{PhD}$ program has been started ${ }^{[1],[5]}$. Moreover the departments have already offered the prestigious degrees leading to MPhil and PhD. In recent past Raiganj University has started different newer areas viz. Sericulture, Computer and Information Science, Microbiology with MPhil \& $\mathrm{PhD}$ degrees all these have been depicted in this paper.

\section{Objective}

The main aim of this paper is to find out the following (but not limited to the following) -

$\square$ To know about the basics of Research atmosphere at Raiganj University.

$\square$ To learn about the foundation and initial infrastructure of Raiganj University.

$\square$ To learn about the Research degrees started at Raiganj University with degrees awarded.

$\square$ To learn about the paper publication trends of Raiganj University in different faculties.

$\square$ To know about the current research areas of various departments of Raiganj University.

$\square$ To learn about the future research potentialities of Raiganj University.

\section{METHODS}

The paper is with empirical in nature and in mainly conducted to gather the knowledge of research atmosphere of Raiganj University of its various departments. For conducting this work questionnaire has been distributed and collected accordingly. The collected data have been analyzed and reported in this paper. The study has been conducted in the month of January-February, 2019. It is also noted that website of Raiganj University (i.e. www.raiganjuniversity.ac.in) also plays a leading role for this work.

\section{Research Work at Raiganj University}

Established in 2015, Raiganj University has different facilities for doing R\&D activities viz. well equipped laboratories, workshop, laboratories, language labs etc. Moreover, the university also has a well equipped library and central computer and information infrastructure facilities. However, few research ornaments was there from the beginning (i.e. from the Raiganj University College period). After its up-gradation into university infrastructures and facilities have been enhanced accordingly.

Faculty members and research scholars are actively engaged in research affairs leading to paper publications in journals, conference proceedings, handbooks and edited books. Importantly many faculty members have published authored and edited books. As a whole, faculty members hold more than 500 published papers (under the following Faculty Council wise)-

$\square$ Faculty Council of Science and Business Management

$\square$ Faculty Council of Arts, Commerce and Law

It is worthy to note that due to the importance of interdisciplinary research few Centres have also been established namely, Environmental Conservation Center (ECC), Centre for Buddhist Studies, Centre for Womens Studies etc. Though the academic departments are actively engaged in R\&D activities and among the core areas of research few important are (department wise; also refer Table 1) - 
Table 1: Department wise Publication Output

\begin{tabular}{cccccc}
\hline Sl. No. & Departments & $\mathbf{2 0 1 6}$ & $\mathbf{2 0 1 7}$ & $\mathbf{2 0 1 8}$ & Total Publication \\
\hline 1 & Botany & 05 & 04 & 02 & $\mathbf{1 1}$ \\
2 & Chemistry & 11 & 11 & 16 & $\mathbf{3 8}$ \\
3 & Computer \& Information Science & 05 & 16 & 32 & $\mathbf{5 3}$ \\
4 & Economics & 01 & 04 & 03 & $\mathbf{0 8}$ \\
5 & Education & NA & 01 & 07 & $\mathbf{0 8}$ \\
6 & Geography & 10 & 17 & 24 & $\mathbf{5 1}$ \\
7 & History & 12 & 08 & 05 & $\mathbf{2 5}$ \\
8 & Philosophy & 07 & 05 & 05 & $\mathbf{1 7}$ \\
9 & Political Science & 07 & 05 & 06 & $\mathbf{1 8}$ \\
10 & Sericulture & 10 & 24 & 18 & $\mathbf{5 2}$ \\
11 & Sociology & 01 & 01 & 03 & $\mathbf{0 5}$ \\
12 & Zoology & 04 & 06 & 04 & $\mathbf{1 4}$ \\
13 & Bengali & 26 & 29 & 23 & $\mathbf{7 8}$ \\
14 & English & 08 & 13 & 16 & $\mathbf{3 7}$ \\
15 & Mathematics & 42 & 39 & 41 & $\mathbf{1 2 2}$ \\
16 & Sanskrit & 07 & 08 & 08 & $\mathbf{2 3}$ \\
17 & Physics & 12 & 13 & 17 & $\mathbf{4 2}$ \\
18 & Commerce & 04 & 05 & 07 & $\mathbf{1 6}$ \\
19 & Law & 02 & 04 & 04 & $\mathbf{1 0}$ \\
20 & Business Administration & - & - & 01 & $\mathbf{0 1}$ \\
21 & Microbiology & 01 & 02 & 10 & $\mathbf{1 3}$ \\
\hline \multicolumn{7}{r}{} & & $\mathbf{1 7 5}$ & $\mathbf{2 1 5}$ & $\mathbf{2 5 0}$ & $\mathbf{6 4 0}$ \\
\hline
\end{tabular}

Botany (Plant resistance, plant growth, fungi, PGPR, PGPF, Mushroom cultivation and vermicomposting, Stress Biology, Molecular plant pathology, Bioinformatics etc)

$\square$ Chemistry (Organic Synthesis, Natural Products, Supramolecular Chemistry, Bioinformatics and Theoretical Chemistry, Inorganic Chemistry etc)

Computer \& Information Science (Business Informatics, Social Informatics, Cloud Computing, Education Technology, E Governance, Big Data \& Emerging Technologies, IT Education)

$\square$ Economics (Econometrics, International Trade, Labor, Health Economics, Development Economics, Population, Agricultural Development \& Economics, Transportation)

Education (Educational Development, Education Technology, E Learning, Mobile Learning etc)

$\square$ Geography (Environmental issue, population, urbanization related issues, agricultural issues, settlement, health and transportation, application of remote sensing and GIS in geography research etc)

History (Socio Economic and Intellectual History, Regional History etc)

$\square$ Philosophy (Ethics-Indian and Western, Phenomenology \& Existentialism, Buddhist Philosophy, Bio Ethics, Environmental Ethics, Philosophy of Religion) 
$\square$ Political Science (Modern history of political thoughts, Good Governance, Political Development, Indian Constitution, Ambedkar Studies, Women Empowerment, Migration, Human Rights)

$\square$ Sericulture (Non mulberry Sericulture and Value addition, Seri Biotechnology, silkworm genetics \& breeding etc)

$\square$ Sociology (Social Development, Socio Economic Culture in North Bengal and North East, Women Trafficking, Community Development)

$\square$ Zoology ( Ecology and Wildlife behavior, Fisheries and Bird diversity, Genetic diversity of mosquito in Uttar Dinajpur, Hydro biological study, Mango mealy bug pest etc)

$\square$ Bengali (Folklore, Local Language, Linguistics, Fiction and Drama, Rabindra Studies etc)

$\square$ English (Comparative Literature, Fiction, Modern Fiction, American Literature, Linguistics, Applied English, Contemporary Literature and Contributors)

$\square$ Mathematics (Applied Mathematics, Real Analysis, Fixed Point Theory, Pure Mathematics)

$\square$ Sanskrit (Local Language, Linguistics, Comparative Literature, Ancient Culture, Sanskrit Grammar, Navya Vyakarana, Samkhya, Yoga, Nyaya, Vaisheshika, Dharmasastra and applied Sanskrit, Vedic Studies)

$\square$ Physics (Organic Photovoltaic, liquid crystal, computational fluid dynamic, X-Ray diffraction, electronics etc)

$\square$ Commerce ( Business and Finance, Indian Trade, Current Trends in Commerce, Marketing, Advanced Accounting etc)

$\square$ Law (Constitutional Law, Technology Law, Legal Studies, Development)

$\square$ Business Administration (Taxation, Applied Business, Organizational Management, Finance etc)

$\square$ Microbiology (Food Microbiology, Agriculture microbiology \& water microbiology, protein chemistry, Bioinformatics, Cell signaling etc)

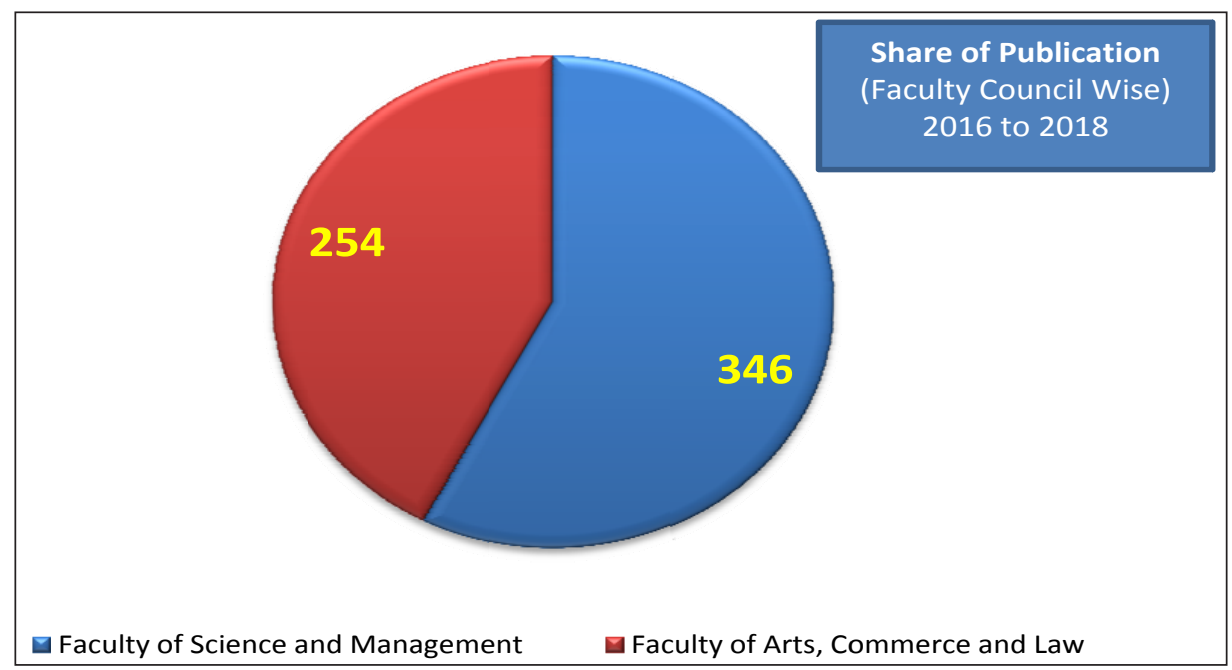

Fig. 1: Share of Publication within the Faculty Council 
The research output at the Raiganj University is noticeable, under its two Faculty Councils Faculty of Science and Management (346); and Faculty of Arts, Commerce and Law (254) total number of publication is 640 in-between 2016 and 2018. It is worthy to mention that the Science Departments viz. Mathematics (122), CIS (53), Sericulture (52), Physics (42) have done good records in terms of number of publications whereas from the Faculty of Arts, Commerce (16) and Law (10) some of the ranked departments in terms of publication are Bengali (78), Geography (51) and English.

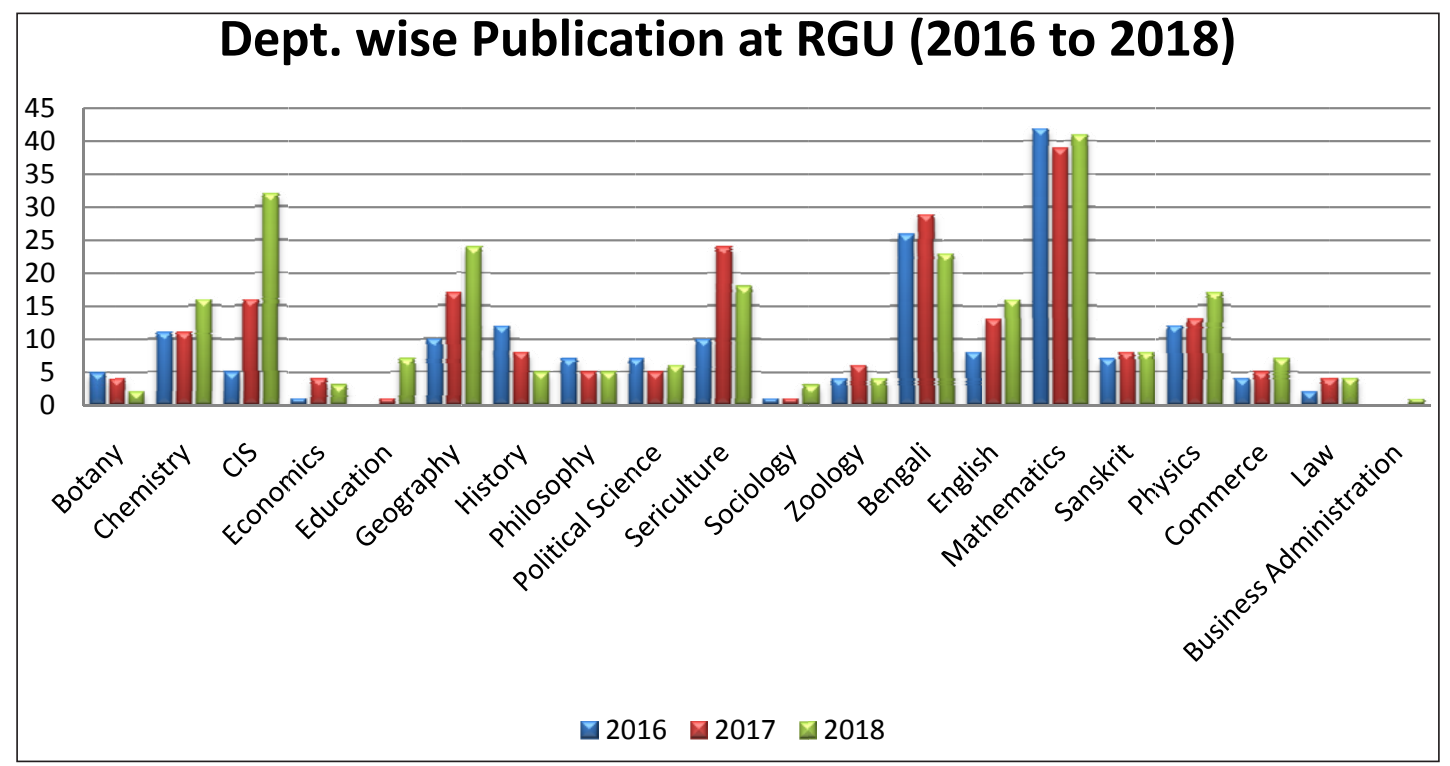

Fig. 2: Department wise publication numbers

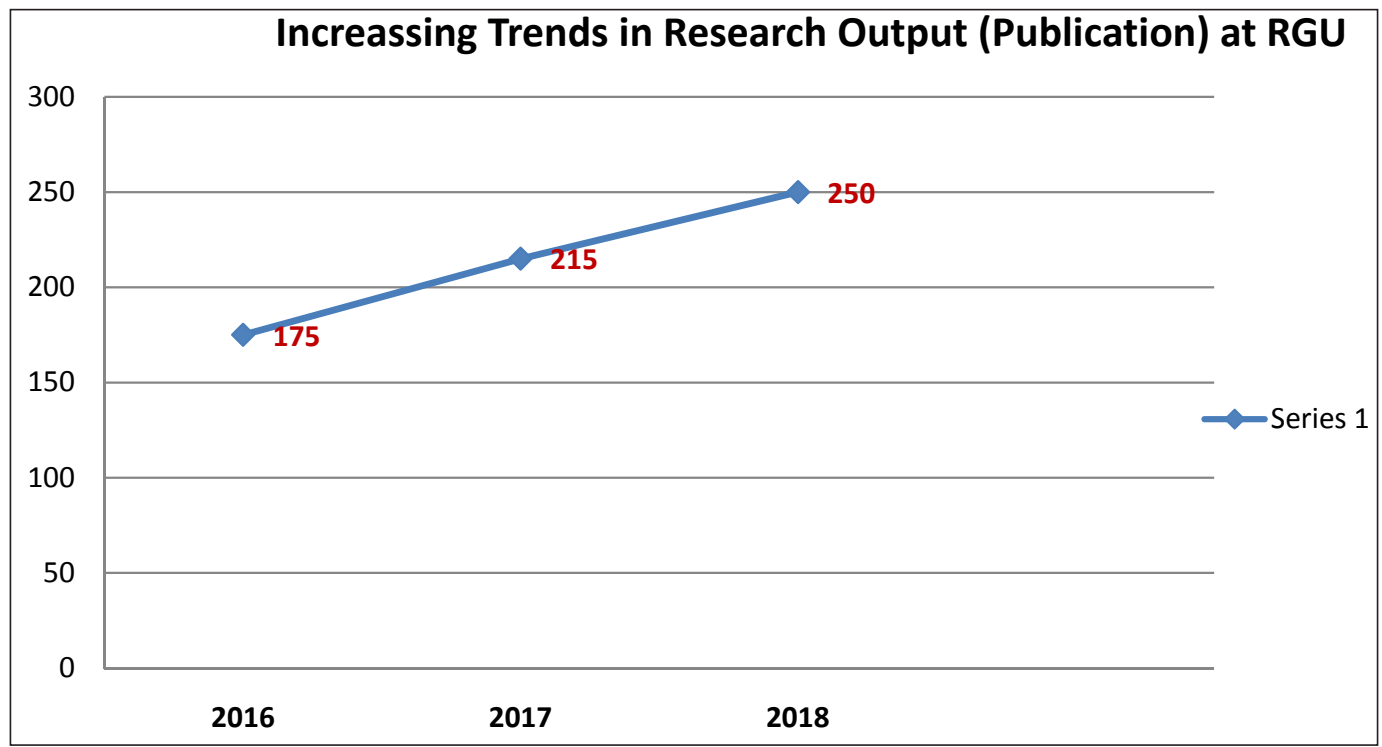

Fig. 3: The trends in increasing publication 
It is also important to note that faculty members from few departments have published good number of authored \& edited books viz. Sanskrit, Geography, Bengali, CIS, Chemistry, Microbiology. Moreover the growth of publication trends is eye-catching; i.e. in the year 2016 total number of publication of the university was 175 , whereas in the year 2017 it was 215 and in the year 2018 it was improved and reached the number to 250. Moreover, the PG students from different departments are also actively participated in the research and academic events and even in few departments (Viz. Chemistry, CIS, Bengali etc) they have contributed publications in different forms Raiganj University has started its research programs leading to M.Phil. and Ph.D. Degree in 17 subjects from its 21 PG Departments (Refer: Fig. 4) which includes Botany, Chemistry, Computer \& Information Science (CIS), Economics, Geography, History, Philosophy, Political Science, Sericulture, Sociology, Zoology, Bengali, English, Mathematics, Sanskrit, Physics, Commerce, Microbiology. It is worthy to mention that the M.Phil. and Ph.D. in some of the innovative areas such as Sericulture, Computer \& Information Science are rarely available in other universities and thus Raiganj University has started a special focus to offer them. Importantly, apart from these Raiganj University has also started a Higher Doctoral Degree or Post Doctoral Degree program leading to D.Litt. in the subjects of Arts, Commerce and Business Management and D.Sc. in the area of Science, Engineering, Technology, Agriculture and Medicine.

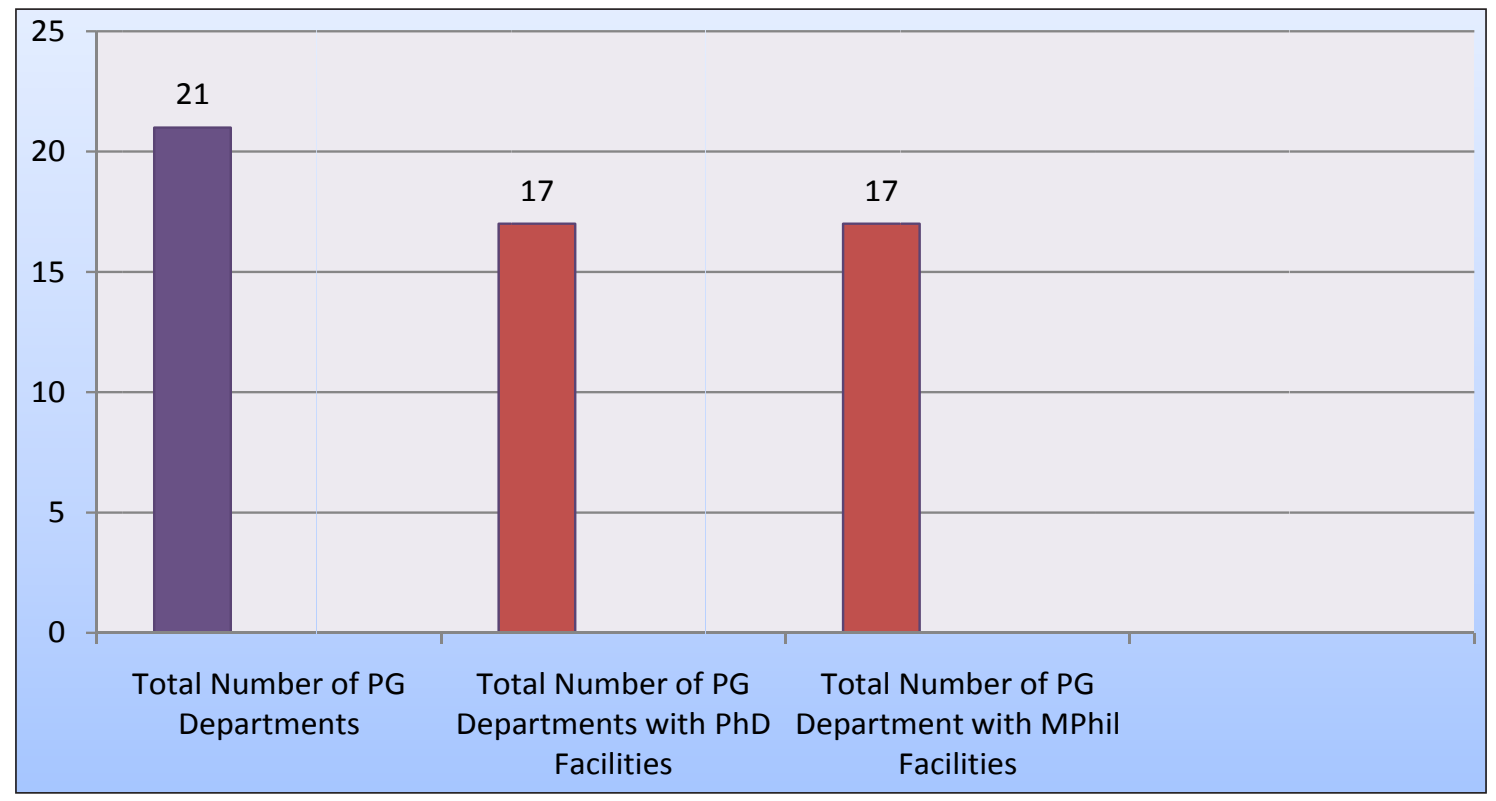

Fig 4: Departments at Raiganj University and M.Phil \& P.hD. facilities

Since its inception (from the year 2015) each year the university offeres Ph.D. and M.Phil degrees. Total four advertisements have been released till and as a result few candidates received degrees leading to Ph.D. The details are depicted in Table 2 and Table 3 depicted about Post/ Higher Doctoral Degrees leading to D.Sc.

It is worthy to mention that apart from these many theses for the award of Ph.D. and M.Phil. in Arts and Science have been submitted and their evaluation. The university also received good amount of research projects from different Central and State Bodies, Ministries and Councils. Moreover industrial and societal 
Table 2: List of Ph.D. Degree awarded by The Raiganj University

\begin{tabular}{|c|c|c|c|c|c|}
\hline $\begin{array}{l}\text { SI. } \\
\text { No. }\end{array}$ & $\begin{array}{l}\text { Name of } \\
\text { Scholars }\end{array}$ & $\begin{array}{l}\text { Name of } \\
\text { Supervisors }\end{array}$ & Title of Thesis & Department & $\begin{array}{l}\text { Year of } \\
\text { Award }\end{array}$ \\
\hline 1 & $\begin{array}{l}\text { Swapan Kumar } \\
\text { Pain }\end{array}$ & Prof. Anil Bhuimali & $\begin{array}{l}\text { Student Participation in the Socio- } \\
\text { Economic Movements of West Bengal in } \\
\text { Post-Colonial Period: } 1947-1977\end{array}$ & History & $26-05-17$ \\
\hline 2 & Sumita Sinha & Dr. Bhaskar Jha & $\begin{array}{l}\text { Dr. B.R. Ambedkar: A Study of His Role } \\
\text { as a Social Reformer and as an Architect } \\
\text { of the Indian Constitution. }\end{array}$ & Political Science & 03-01-18 \\
\hline 3 & Goutam Sarkar & Dr. Bhaskar Jha & $\begin{array}{l}\text { Changing Scenario of Indian Federalism: } \\
\text { An Analytical Study on its Reform \& } \\
\text { Restructure }\end{array}$ & Political Science & $16-02-18$ \\
\hline 4 & $\begin{array}{l}\text { Biswajit } \\
\text { Barman }\end{array}$ & Dr. Tapash Mohanta & $\begin{array}{l}\text { Media Ethics and its Relevance in } \\
\text { Contemporary Era }\end{array}$ & Philosophy & $25-06-18$ \\
\hline 5 & Jhumu Saha & Prof. Anil Bhuimali & $\begin{array}{l}\text { Ambedkar on Casteism and its } \\
\text { Historical, Economical and Philosophical } \\
\text { Implication }\end{array}$ & Philosophy & $26-05-18$ \\
\hline 6 & Mukul Saha & Prof. Anil Bhuimali & $\begin{array}{l}\text { Examining the Development Perspective } \\
\text { for Eastern States of India }\end{array}$ & Economics & $18-06-18$ \\
\hline 7 & Sanjib Mandal & Prof. Anil Bhuimali & $\begin{array}{l}\text { Economic Development of Sikkim in the } \\
\text { Post-Reform Regime }\end{array}$ & Economics & $10-10-18$ \\
\hline 8 & Arindam Dutta & $\begin{array}{l}\text { Dr. Rumki Sarkar \& } \\
\text { Dr. Ashoke Das }\end{array}$ & $\begin{array}{l}\text { A Study on Connectivity and } \\
\text { Accessibility of Road Transport Network } \\
\text { in Uttar Dinajpur District, West Bengal }\end{array}$ & Geography & $10-10-18$ \\
\hline 9 & $\begin{array}{l}\text { Purna Chandra } \\
\text { Barman }\end{array}$ & $\begin{array}{l}\text { Dr. Md. Rabiul Islam } \\
\text { \& Dr. Ashoke Das }\end{array}$ & $\begin{array}{l}\text { Influence of Second Order Effects on } \\
\text { Convective Transport in Porous Media }\end{array}$ & Physics & $02-11-18$ \\
\hline 10 & $\begin{array}{l}\text { Krishnadhan } \\
\text { Sarkar }\end{array}$ & $\begin{array}{l}\text { Prof. K.S. Tiwary \& } \\
\text { Dr. Ashoke Das }\end{array}$ & $\begin{array}{l}\text { Investigation on Fixed Point Theorems In } \\
\text { Metric and Banach Spaces }\end{array}$ & Mathematics & $26-12-18$ \\
\hline
\end{tabular}

Table 3: List of Post Doctoral Degree awarded by the Raiganj University

\begin{tabular}{lllll}
\hline $\begin{array}{l}\text { Sl. } \\
\text { No. }\end{array}$ & $\begin{array}{l}\text { Name of } \\
\text { Scholars }\end{array}$ & Title of Thesis & Award & Year \\
\hline 1 & K.S. Tiwary & $\begin{array}{l}\text { Study on Fixed and Periodic Point to Point Valued and Set } \\
\text { Valued Mappings in Metric and Normed Linear Spaces }\end{array}$ & $\begin{array}{l}\text { D.Sc. in } \\
\text { Mathematics }\end{array}$ & $29-05-17$ \\
\hline
\end{tabular}

organizations also offered the projects among the faculty members from different Applied Sciences and few Humanities disciplines. During this last three years faculty members and officers from different departments and sections have actively participated in the academic events leading to Conferences, Seminars, Symposiums, Congress, Workshop, Faculty Development Program, Short Term Course etc. Moreover, the PG students from different departments are also actively participated in the research and academic events and even in few departments (Viz. Chemistry, CIS, Bengali etc.) they have contributed publications in different forms. It is worthy to note that faculty members from different departments viz. Chemistry, Computer \& Information Science, Geography, Microbiology, Sericulture have received different kind of national and international awards for their research contribution and performances.

It is worthy to note that due to significant improvement of research and development teachers of different departments have received various awards (such as A. Bhuimali, D.K. Roy, K.S. Tiwary, S. Saha, T. Pal, K. Ghatani, K. Biswas, A.K. Mandal, P.K. Paul, A. Mandal) and projects funded by different agencies viz. 
UGC, WB Dept. of ST. ICSSR, CSIR, DBT, ICHR, ICSSR, ICMR and different industries. Moreover the university also has established strategic alliances/ collaboration with other institutions viz. University of Albany; US, Uttar Bangla University College; Bangladesh, McGill University; US, Glasgow University; UK etc.

\section{Suggestions}

There are different initiative have been taken for the modernization of the education systems of the Raiganj University in recent past apart from 22 PG Department 10 Centers have been established viz. Centre for Manuscriptology (2018), Centre for Heritage Museum (2018), Centre for Gandhian Studies (2018), Centre for Women Studies (2018), Centre for Vedic Studies (2018), Centre for Buddhist Studies (2018) and also Centre for Differently Abled Persons (2018) etc and in future these centres need to offer academic programs leading to Certificate, Diploma and even Bachelors and Masters Program of the emerging areas based on trend and importance.

Moreover Research Programs in the Interdisciplinary areas may be started by the Departments and Centres as well. It is worthy to have clustered School (of academics \& research) or Colleges viz.

$\square$ School/ College of Biological Sciences (may be constituted with few current or future departments viz. Sericulture, Botany, Zoology, Microbiology and future emerging departments);

School/ College of Pure Sciences (may be constituted with few current or future departments viz. Physics, Chemistry, Mathematics and future emerging departments);

$\square$ School/ College of Mathematical Sciences (may be constituted with few current or future departments viz. Mathematics, Statistics departments);

$\square$ School/ College of Information Sciences (may be constituted with few current or future departments viz. Computer Science, IT, Media Studies future emerging departments);

$\square$ School/ College of Social Sciences (may be constituted with few current or future departments viz. History, Geography, Political Sciences, Philosophy, Education and future emerging departments)

$\square$ School/ College of Commerce and Management (may be constituted with few current or future departments viz. Commerce, Management, Hotel Management and future emerging departments),

$\square$ School/ College of Language and Literature (may be constituted with few current or future departments English, Bengali, Sanskrit and future emerging departments) etc.

However, the centres may also clustered into the proposed and above mentioned Schools/ Colleges for better academic and research dealing.

\section{CONCLUSION}

Research is a vital source for the development of any kind ${ }^{[3],[4], \text { [6] }}$. The state of West Bengal is growing rapidly in terms of development of research affairs. Several new universities have been made in recent years in different part of the states. The Raiganj University has taken important initiative for the development 
of research affairs as much as possible and as a result, apart from the department and new units various Centers have been established in recent past. Though in coming year more interdisciplinary programs are needed to offer with proper and healthy collaboration. Moreover, the Centers which are established need to involve more deeply with the research activities in future leading to publications, academic event development and so on.

\section{REFERENCES}

1. Chandrasekhar, C.P. 1993. Agrarian change and occupational diversification: Non-agricultural employment and rural development in West Bengal. The Journal of Peasant Studies, 20(2): 205-270.

2. Chattopadhyay, D. 2004. Knowledge and skills of Anganwadi workers in Hooghly district West Bengal. Indian Journal of Community Medicine, 29(3): 4.

3. Drèze, J. \& Murthi, M. 2001. Fertility, education, and development: evidence from India. Population and development Review, 27(1): 33-63.

4. Krishnamurthy, M. \& Kemparaju, T.D. 2011. Institutional repositories in Indian universities and research institutes: A study. Program, 45(2): 185-198.

5. Prathap, G. \& Gupta, B.M. 2009. Ranking of Indian universities for their research output and quality using a new performance index. Current Science, 97(6): 751-52.

6. Sharma, D. 2009. Mapping international relations teaching and research in Indian universities. International Studies, 46(1-2): 69-88.

7. Umashankar, V. \& Dutta, K. 2007. Balanced scorecards in managing higher education institutions: an Indian perspective. International Journal of Educational Management, 21(1): 54-67. 